\title{
Self-assembly behaviors of perylene- and naphthalene-crown macrocycle conjugates in aqueous medium
}

\author{
Xin Shen ${ }^{1}$, Bo $\mathrm{Li}^{1}$, Tiezheng Pan ${ }^{1}$, Jianfeng Wu${ }^{1}$, Yangxin Wang ${ }^{1}$, Jie Shang ${ }^{1}$, Yan $\mathrm{Ge}^{1}$, \\ Lin $\operatorname{Jin}^{* 1}$ and Zhenhui Qi ${ }^{* 1,2}$
}

\section{Letter}

\section{Address:}

${ }^{1}$ Sino-German Joint Research Lab for Space Biomaterials and Translational Technology, School of Life Sciences, Northwestern Polytechnical University, Xi'an, Shaanxi 710072, P. R. China and ${ }^{2}$ Institute of Biomedical Materials \& Engineering (IBME), Northwestern Polytechnical University, Xi'an, Shaanxi 710072, P. R. China

Email:

Lin Jin* - jinlin@nwpu.edu.cn; Zhenhui Qi - qi@nwpu.edu.cn

${ }^{*}$ Corresponding author

Keywords:

aqueous medium; crown ether; macrocycle; perylene diimide derivative; self-assembly
Beilstein J. Org. Chem. 2019, 15, 1203-1209.

doi:10.3762/bjoc. 15.117

Received: 01 March 2019

Accepted: 14 May 2019

Published: 03 June 2019

This article is part of the thematic issue "Novel macrocycles - and old ones doing new tricks".

Guest Editor: W. Jiang

(C) 2019 Shen et al.; licensee Beilstein-Institut. License and terms: see end of document.

\begin{abstract}
The synthesis of conjugates of perylene diimide (PDI) and naphthalene diimide (NDI) modified with two benzo-21-crown-7 ethers (B21C7) are herein described. Their self-assembly behavior in various solvents was investigated particularly in aqueous medium, due to the recently discovered hydrophilic properties of B21C7 crown macrocycle. An unexpected fluorescence quenching phenomenon was observed in the PDI-B21C7 macrocycle conjugate in chloroform. The detailed UV-vis absorption and fluorescence spectra of these PDI/NDI derivatives in different solvents as well as their morphologies were investigated.
\end{abstract}

\section{Introduction}

Owing to their unique physicochemical properties, self-assemblies have been recognized as a type of exciting nanomaterials with tremendous potential for research and commercial applications [1-6]. Thanks to the development of supramolecular chemistry, the ordered structures could be obtained through programmed self-assembly coupled with covalent chemical synthesis [7]. In fact, supramolecular technology has shown great importance in various kinds of functional materials, including natural protein complexes [8-10], hydrogels [11-13], carbonbased materials [14-17], self-healing materials [18-23], and composite materials [24-26]. Moreover, several new proof-of- concept applications of supramolecular assemblies are also of increasing interest, specifically in the fields of energy generation and storage [27], water treatment and environmental remediation $[28,29]$, and healthcare and biomedical engineering [3032].

Nowadays, as the research in supramolecular chemistry is expanding into the aqueous realm, a systematic understanding of the interaction relationship of supramolecular self-assemblies and aqueous medium is becoming increasingly important [33-36]. As the first generation of macrocyclic hosts, crown 
ethers, have been widely used as building blocks for supramolecular assemblies in the past two decades [37-53], mainly in the fabrication of crown ether-based threaded or interlocked assemblies in organic solvents [54]. However, we recently found that benzo-21-crown-7 (B21C7) displays impressive high water solubility in comparison with other macrocyclic hosts [55]. Moreover, the conjugation of $\mathrm{B} 21 \mathrm{C} 7 \mathrm{~s}$ to the well-known supramolecular BTA core leads to the observation of special topological effects on ion selectivity in water [56]. Following this water-centered view, we further explored a new type of supramolecular polymeric adhesive based on B21C7 derived low-molecular weight (LMW) monomer, in which the water molecules serve as essential co-monomers to the polymerization process, rather than as solvent [57]. Compared with their linear glycol chain counterparts, B21C7 shows great potential to be an easy-to-accessed building block to probe the non-covalent interactions and chemical transformations influenced by water molecules.

Perylene diimide (PDI) and naphthalene diimide (NDI) are polycyclic aromatic chromophores widely used in the dye industry and have been applied as advanced materials in the fields of fluorescence labeling [58,59], organic semiconducting devices [60,61], and light harvesting [62-65]. PDI and NDI units have been extensively incorporated into functional supramolecular architectures through hydrogen bonding and metal ion coordination in nonpolar solvents [66-68]. Compared with NDI, PDI has more aromatic rings to generate stronger intermo- lecular $\pi-\pi$ stacking, leading to molecular aggregates more easily, and these aggregates or supramolecular assemblies can give rise to desirable properties, such as charge transport and photophysical properties [69-74]. While the morphologies of these aggregates were greatly influenced by solvents, molecular structures and shapes, as well as the fraction of hydrophilic and/or hydrophobic parts [75-81]. By far, little was known to the self-assembly behaviors of B21C7 crown macrocycle functionalized PDIs/NDIs in aqueous solution, even though there have been several reports about crown ether-functionalized PDIs or NDIs, which mostly focused on their interactions with metal ions [82-85]. Herein, we attempted to combine these two classical organic moieties and crown macrocycle together and reported the PDI- and NDI-B21C7 conjugates. Their self-assemblies behaviors in aqueous medium were thus probed.

\section{Results and Discussion}

The synthetic route toward compounds $\mathbf{1}$ and $\mathbf{2}$ is shown in Scheme 1. Initially, the water-soluble crown macrocycle $\mathbf{3}$ was synthesized according to reported protocols, by using potassium cations as template $[86,87]$. The primary amine group in $\mathbf{3}$ offers diverse reaction pathways to design crown ethers appended LMW gelators, dendrimers and polymers [88-92]. In order to conjugate $\mathrm{B} 21 \mathrm{C} 7$ onto PDI, compound $\mathbf{3}$ and 4-dimethylaminopyridine (DMAP) were dissolved in ethylene glycol, then 3,4,9,10-perylenetetracarboxylic dianhydride (PDI) was charged and suspended in the solution. The mixture was

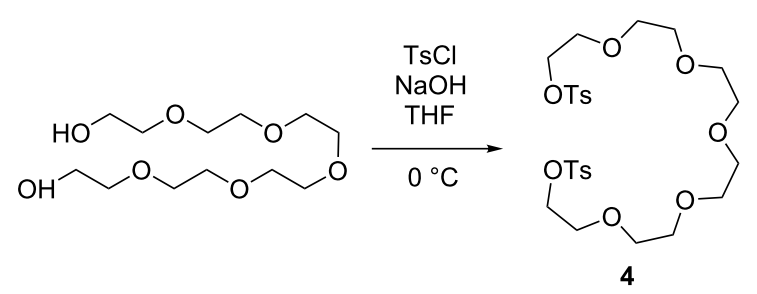<smiles>N#Cc1ccc(O)c(O)c1</smiles>

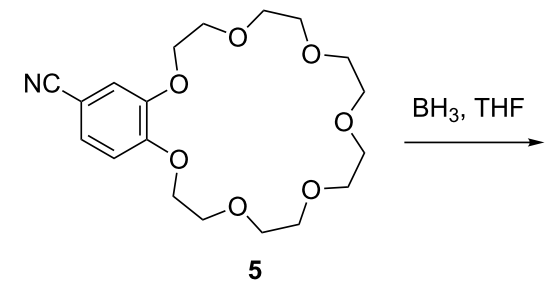

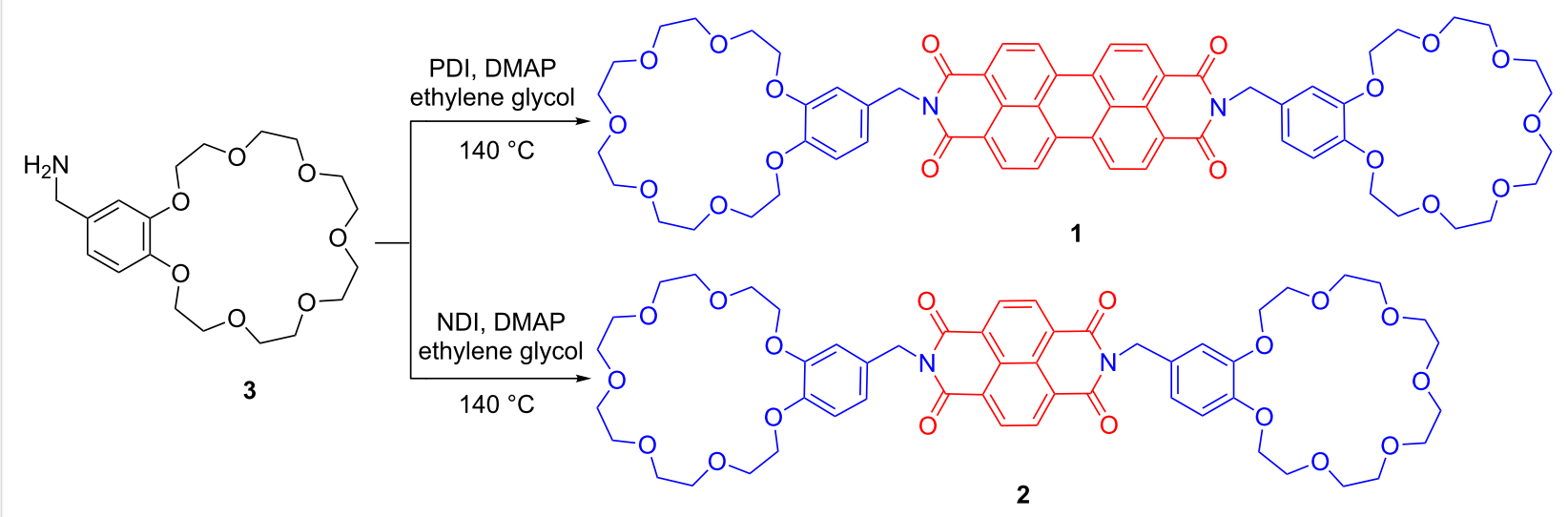


heated to $140{ }^{\circ} \mathrm{C}$ and stirred overnight. After cooling down to room temperature, the reaction mixture was dissolved in $\mathrm{CH}_{2} \mathrm{Cl}_{2}$. The solution was washed by diluted hydrochloric acid $(0.05 \mathrm{M})$ and saturated brine, respectively. After the drying process, compound 1 was obtained with moderate yield. Compound $\mathbf{2}$ was prepared via a similar method except that NDI was used instead of PDI. All the final compounds were carefully characterized by ${ }^{1} \mathrm{H}$ and ${ }^{13} \mathrm{C}$ NMR spectroscopy and electrospray ionization mass spectroscopy (ESI-MS, Supporting Information File 1, Figures S1-S8).

UV-vis absorption and fluorescence spectra of $\mathbf{1}$ in different solvents, including $\mathrm{CHCl}_{3}, \mathrm{MeCN}, \mathrm{MeOH}, \mathrm{H}_{2} \mathrm{O}$, and mixed solvent $\mathrm{CHCl}_{3} / \mathrm{MeCN}(\mathrm{v} / \mathrm{v}=2: 1)$, were recorded to investigate its self-assembly behavior. Figure 1a shows the UV-vis absorption spectra of 1 in solvents with different polarity. The spectrum of 1 in the less polar solvent $\mathrm{CHCl}_{3}$ shows a well-resolved vibronic structure $(0-0,0-1$, and $0-2$ transitions of PDI molecules) with three characteristic absorption bands at 530, 485, and $469 \mathrm{~nm}$, respectively [67]. However, the ratio of intensities of the bands derived from $0-0$ and $0-1$ transitions is around 1.53 , indicating that 1 in $\mathrm{CHCl}_{3}$ seems do not only exist in monomeric state, but also in kind of $\pi-\pi$ aggregated state $[93,94]$. When more polar solvent $\mathrm{MeCN}$ or $\mathrm{MeOH}$ were used, merely a broad and very weak absorption band was observed. All the weak and disappearing bands indicate the overlapping of PDI chromophores to form $J$-type aggregates in polar solvents [84]. The intensities of the characteristic absorption bands of 1 in mixed solvents of $\mathrm{CHCl}_{3} / \mathrm{MeCN}(\mathrm{v} / \mathrm{v}=2: 1)$ are even higher than those of $\mathbf{1}$ in pure $\mathrm{CHCl}_{3}$, indicating a better solubility of $\mathbf{1}$ in the mixed solvents. We were encouraged to investigate the $\mathrm{UV}$-vis absorption behavior of $\mathbf{1}$ in mixed solvents of $\mathrm{CHCl}_{3}$ and $\mathrm{MeCN}$ with different volume ratios (Supporting Information File 1, Figure S9). It is observed that when the volume proportion of $\mathrm{MeCN}$ in the mixed solvent is below $70 \%$, the $\mathrm{UV}$-vis absorption intensity of $\mathbf{1}$ is higher than that in pure $\mathrm{CHCl}_{3}$. However, when the volume proportion of $\mathrm{MeCN}$ increases to $80 \%$, the UV-vis absorption intensities decrease

\section{a)}
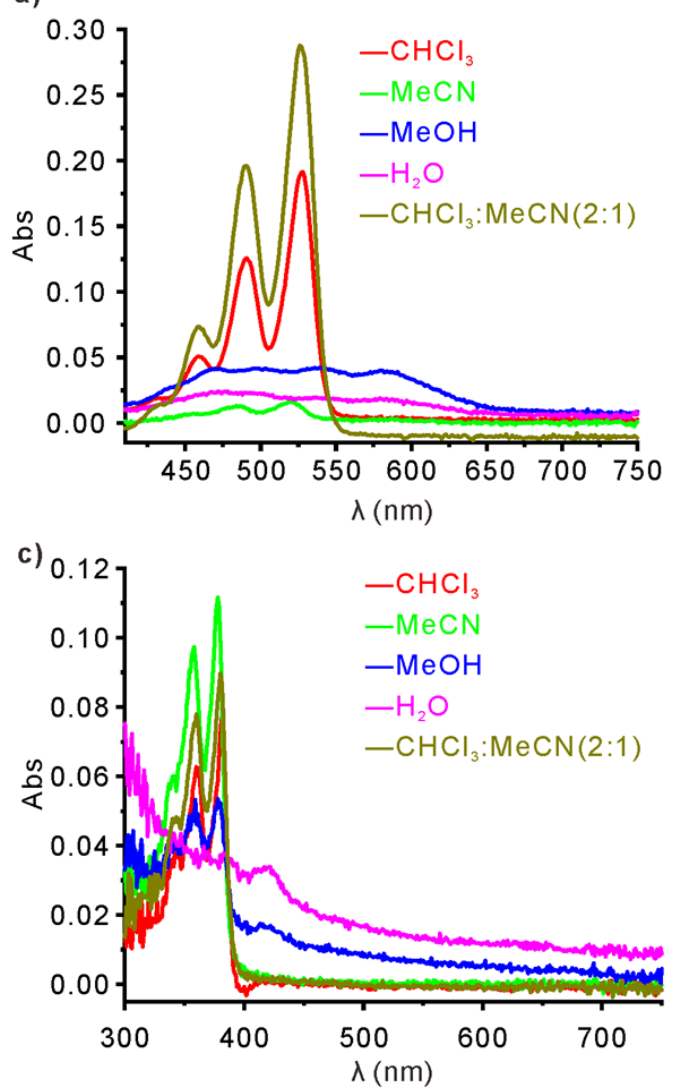
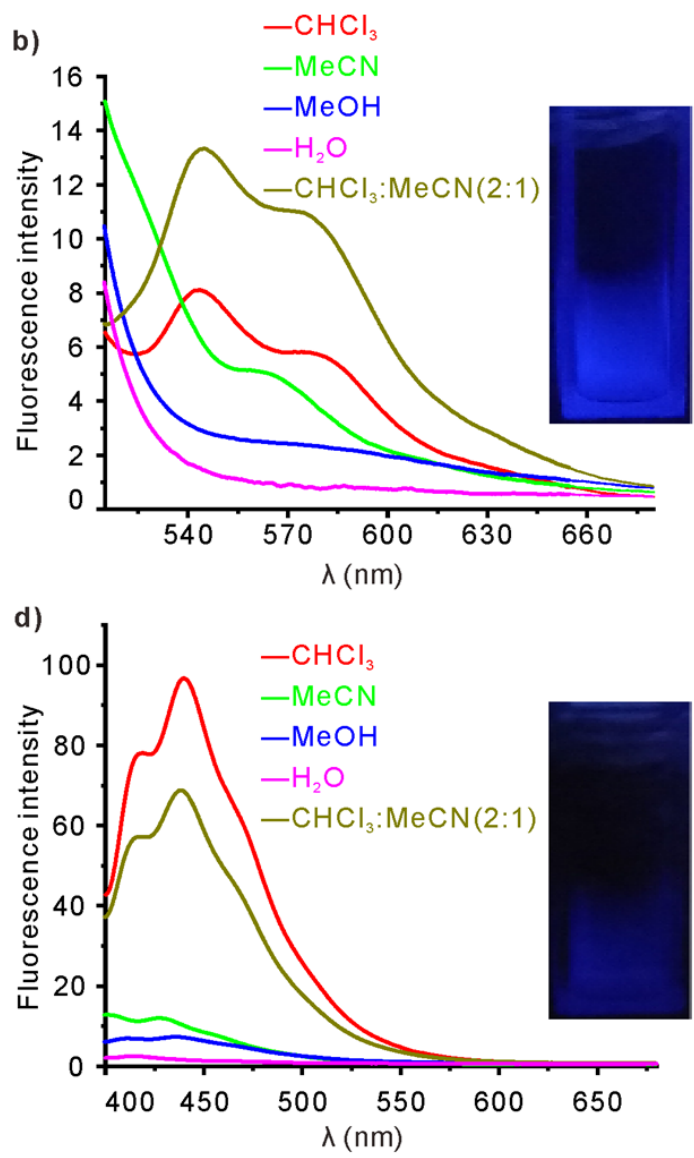

Figure 1: (a) UV-vis absorption spectra and (b) fluorescence spectra $\left(\lambda_{\mathrm{ex}}=490 \mathrm{~nm}\right)$ of 1 in different solvents (inset: photograph of 1 in $\mathrm{CHCl} 3$ irradiated under $365 \mathrm{~nm}$ ); (c) UV-vis absorption spectra and (d) fluorescence spectra $\left(\lambda_{\mathrm{ex}}=360 \mathrm{~nm}\right.$ ) of 2 in different solvents (inset: photograph of 2 in $\mathrm{CHCl}_{3}$ irradiated under $365 \mathrm{~nm}$ ). The concentration of 1 or 2 in the solutions is $5.0 \times 10^{-6} \mathrm{M}$. All the measurements were performed at room temperature. 
dramatically. The variations of UV-vis absorbance of $\mathbf{1}$ in the mixed solvents with different ratios are correlative to its solubility changes, indicating that the solubility of $\mathbf{1}$ in solvents are probably influenced by the interactions between both PBI unit and crown ether units with solvents. The fluorescence spectra of $1\left(\lambda_{\mathrm{ex}}=490 \mathrm{~nm}\right)$ in different solvents also imply the varied selfassembly behavior (Figure 1b). The fluorescence of $\mathbf{1}$ in $\mathrm{CHCl}_{3}$ is strong with a broad emission band at $520-600 \mathrm{~nm}$, and becomes even stronger when $\mathrm{CHCl}_{3} / \mathrm{MeCN}(\mathrm{v} / \mathrm{v}=2: 1)$ is used as solvent. But due to the aggregation-caused quenching (ACQ) effect, the fluorescence of $\mathbf{1}$ in $\mathrm{MeCN}$ decreased dramatically, and was almost totally quenched in $\mathrm{MeOH}$ and $\mathrm{H}_{2} \mathrm{O}$. It is surprising to us that the fluorescence of $\mathbf{1}$ in $\mathrm{CHCl}_{3}$ is also quenched even at such a low concentration $\left(5.0 \times 10^{-6} \mathrm{M}\right)$, as only a faint blue fluorescent emission of 1 could be detected (Figure $1 \mathrm{~b}$ inset). According to previous reports, such a fluorescent quenching indicated the formation of a dimeric structure [67,95], and the electron rich substituents at the imide nitrogen should play an important role $[96,97]$.

For comparison, UV-vis absorption and fluorescence spectra of 2 in the above-tested five solvent systems were also recorded. Because of the relatively weaker $\pi-\pi$ stacking effect of the NDI units comparing with PDI units, 2 has a better solubility in the organic solvents. Consequently, the UV-vis absorption bands of $\mathbf{2}$ in all the organic solvents can be clearly observed but with an overall hypsochromic shift (Figure 1c). The aggregation of 2 also takes place in the solvents with high polarity, such as $\mathrm{MeOH}$ and $\mathrm{H}_{2} \mathrm{O}$, in which 2 shows weak or even no UV-vis absorption. Similar to $\mathbf{1}, \mathbf{2}$ also shows a strong fluorescence in $\mathrm{CHCl}_{3}$ and mixed $\mathrm{CHCl}_{3} / \mathrm{MeCN}(\mathrm{v} / \mathrm{v}=2: 1$, Figure 1d). In the polar solvents $\mathrm{MeCN}$ and $\mathrm{MeOH}$, fluorescence of $\mathbf{2}$ becomes much weaker, and is almost totally quenched in $\mathrm{H}_{2} \mathrm{O}$.

In order to observe the aggregates formed by $\mathbf{1}$ and $\mathbf{2}$ visually in solutions, transmission electron microscopy (TEM) was utilized. First, the aggregates of $\mathbf{1}$ formed in $\mathrm{CHCl}_{3}$ and $\mathrm{MeCN}$ were investigated. As shown in Figure 2a, micelle-like assemblies of 1 were observed, while, because of the higher polarity of $\mathrm{MeCN}$, the aggregation of 1 through $\pi-\pi$ stacking was considerably enhanced forming linear assemblies (Figure 2b). Interestingly, when imposed to an aqueous medium through adding water slowly into $\mathrm{MeCN}$ solution under ultrasonication yielding a mixture solvent of $\mathrm{H}_{2} \mathrm{O} / \mathrm{MeCN}=10: 1(\mathrm{v} / \mathrm{v}), \mathbf{1}$ assembled into a well-defined nanobelt in extremely polar aqueous environment, which further entangled into networks (Figure 2c)
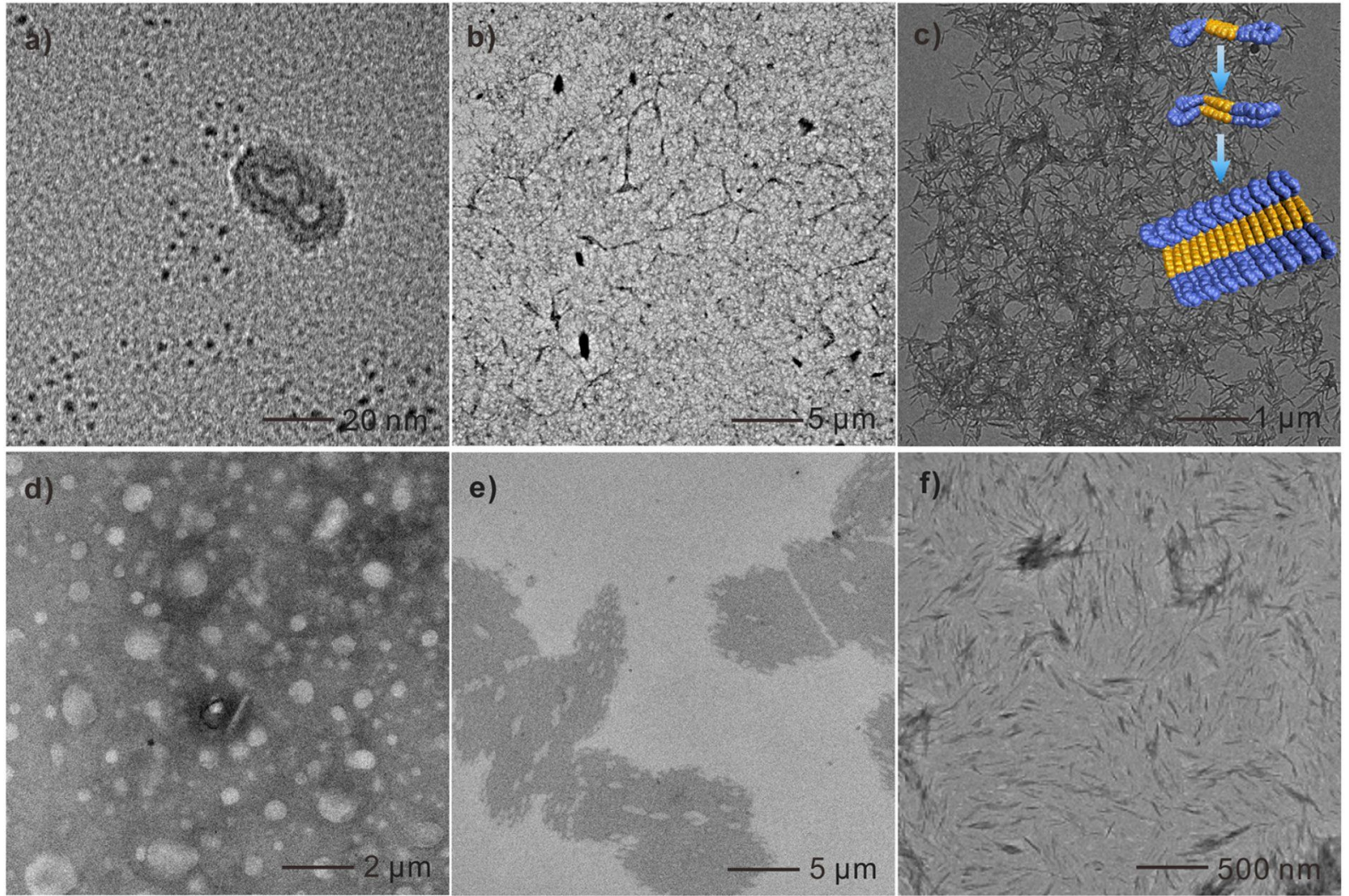

Figure 2: TEM images of 1 aggregates in (a) $\mathrm{CHCl}_{3}$, (b) $\mathrm{MeCN}$, and (c) $\mathrm{H}_{2} \mathrm{O} / \mathrm{MeCN}(\mathrm{v} / \mathrm{v}=10: 1$ ) (inset: schematic space-filling models illustrating the self-assembly of 1); TEM images of 2 aggregates in (d) $\mathrm{CHCl}_{3}$, (e) $\mathrm{MeCN}$, and (f) $\mathrm{H}_{2} \mathrm{O} / \mathrm{MeCN}(\mathrm{v} / \mathrm{v}=10: 1)$. Concentration of solutions for all the TEM analysis is $1 \times 10^{-4} \mathrm{M}$. 
[68]. Previously, Würthner's group reported the self-assembly of a trioligo(ethylene glycol)-conjugated PDI system which can self-assemble into similar nanobelt structures [79]. Therefore, we inferred that the B21C7 macrocycle units have a similar solubilizing and induction effect like oligo(ethylene glycol) chains for the self-assembly behavior of PDI derivatives. Due to the weaker $\pi-\pi$ stacking of 2 leading to a less regular packing arrangement, no regular morphology was observed when $\mathrm{CHCl}_{3}$ or $\mathrm{MeCN}$ was used as solvent (Figure $2 \mathrm{~d}$ and $2 \mathrm{e}$ ), and only a short nanobelt was observed in $\mathrm{H}_{2} \mathrm{O} / \mathrm{MeCN}(\mathrm{v} / \mathrm{v}=10: 1$, Figure 2f). The TEM characterization result was corroborated well by a dynamic light scattering (DLS) measurement (Figure S10, Supporting Information File 1), which was proven to be a convenient method to study aggregation behavior in solvents $[98,99]$. It was found that the average diameter of aggregates of 1 in $\mathrm{CHCl}_{3}(100 \mu \mathrm{M})$ was around $31.1 \mathrm{~nm}$. The size of aggregated 1 in $\mathrm{MeCN}$ was ranging from around 40 to $200 \mathrm{~nm}$ centered at $81.8 \mathrm{~nm}$, while it further increased to $840.1 \mathrm{~nm}$ in $\mathrm{H}_{2} \mathrm{O} / \mathrm{MeCN}(\mathrm{v} / \mathrm{v}=10: 1)$. However, the DLS measurement results of aggregates formed by 2 in either $\mathrm{CHCl}_{3}$ or $\mathrm{MeCN}$ was unrepeatable, possibly due to the irregular packing in these solvents. But DLS measurement result showed that the size of aggregates of 2 formed in $\mathrm{H}_{2} \mathrm{O} / \mathrm{MeCN}(\mathrm{v} / \mathrm{v}=10: 1)$ was centered at $576.8 \mathrm{~nm}$. It should be noted that the aggregates formed by $\mathbf{1}$ and $\mathbf{2}$ with specific shapes were obtained immediately after the preparation of solutions, without days' evolution process [77].

\section{Conclusion}

In summary, we synthesized crown ether-functionalized PDI and NDI derivatives, and investigated their solvent-dependent solubility and self-assembly behaviors. It was found that the polarity of solvents have an important impact on their selfassembly behavior, thus inducing obvious changes in their UV-vis absorption and fluorescence properties. An unexpected fluorescence quenching phenomenon was observed in the PDI-B21C7 macrocycle conjugate in chloroform. Through TEM characterization, it was illustrated that in aqueous medium, both PDI and NDI derivatives containing crown ether units could quickly self-assembly into nanobelt aggregates, during which the crown ether units exhibited the similar solubilizing and induction effect like oligo(ethylene glycol) chains.

\section{Supporting Information}

\section{Supporting Information File 1}

Experimental and analytical data.

[https://www.beilstein-journals.org/bjoc/content/

supplementary/1860-5397-15-117-S1.pdf]

\section{Acknowledgements}

We gratefully acknowledge financial support from the Thousand Talents Program of China, Postdoctoral Innovative Talents Supporting Project (BX20180255) of China, Key R\&D Program of Shaanxi Province (2019KW-031, 2019KW-038), Natural Science Basic Research Plan in Shaanxi Province of China (2018JQ2017), Fundamental Research Funds for the Central Universities (3102018zy051, 3102018jcc007, 3102017OQD044, 3102017OQD045, 3102017OQD040, 3102017OQD115, 3102018zy051, 3102019ghxm005), and State Key Laboratory of Solidification Processing in NPU (SKLSP201817). We thank the Analytical \& Testing Center of NPU for the characterization of materials.

\section{ORCID ${ }^{\circledR}$ iDs}

Yangxin Wang - https://orcid.org/0000-0001-5030-7279

\section{References}

1. Ariga, K.; Hill, J. P.; Lee, M. V.; Vinu, A.; Charvet, R.; Acharya, S. Adv. Mater. (Weinheim, Ger.) 2009, 9, 014109. doi:10.1088/1468-6996/9/1/014109

2. Abbas, M.; Zou, Q.; Li, S.; Yan, X. Adv. Mater. (Weinheim, Ger.) 2017, 29, 1605021. doi:10.1002/adma.201605021

3. Schacher, F. H.; Rupar, P. A.; Manners, I. Angew. Chem., Int. Ed. 2012, 51, 7898-7921. doi:10.1002/anie.201200310

4. Li, X.; locozzia, J.; Chen, Y.; Zhao, S.; Cui, X.; Wang, W.; Yu, H.; Lin, S.; Lin, Z. Angew. Chem., Int. Ed. 2018, 57, 2046-2070. doi:10.1002/anie.201705019

5. Chen, L.-J.; Yang, H.-B. Acc. Chem. Res. 2018, 51, 2699-2710. doi:10.1021/acs.accounts.8b00317

6. Li, B.; Wang, B.; Huang, X.; Dai, L.; Cui, L.; Li, J.; Jia, X.; Li, C. Angew. Chem., Int. Ed. 2019, 58, 3885-3889. doi:10.1002/anie.201813972

7. Lehn, J.-M. Angew. Chem., Int. Ed. Engl. 1988, 27, 89-112. doi:10.1002/anie.198800891

8. Pandya, M. J.; Spooner, G. M.; Sunde, M.; Thorpe, J. R.; Rodger, A.; Woolfson, D. N. Biochemistry 2000, 39, 8728-8734. doi:10.1021/bi000246g

9. Mulyasasmita, W.; Lee, J. S.; Heilshorn, S. C. Biomacromolecules 2011, 12, 3406-3411. doi:10.1021/bm200959e

10. Luo, Q.; Hou, C.; Bai, Y.; Wang, R.; Liu, J. Chem. Rev. 2016, 116, 13571-13632. doi:10.1021/acs.chemrev.6b00228

11. Xu, Y.; Sheng, K.; Li, C.; Shi, G. ACS Nano 2010, 4, 4324-4330. doi:10.1021/nn101187z

12. Hauser, C. A. E.; Deng, R.; Mishra, A.; Loo, Y.; Khoe, U.; Zhuang, F.; Cheong, D. W.; Accardo, A.; Sullivan, M. B.; Riekel, C.; Ying, J. Y.; Hauser, U. A. Proc. Natl. Acad. Sci. U. S. A. 2011, 108, 1361-1366. doi:10.1073/pnas.1014796108

13. Sutar, P.; Suresh, V. M.; Jayaramulu, K.; Hazra, A.; Maji, T. K. Nat. Commun. 2018, 9, No. 3587. doi:10.1038/s41467-018-05818-w

14. Sano, M.; Kamino, A.; Okamura, J.; Shinkai, S. Nano Lett. 2002, 2, 531-533. doi:10.1021/nl025525z

15. Patra, N.; Song, Y.; Král, P. ACS Nano 2011, 5, 1798-1804. doi:10.1021/nn102531h

16. Poonia, M.; Gupta, R. K.; Manjuladevi, V.; Gupta, S. K.; Akhtar, J. J. Nanopart. Res. 2014, 16, 2572. doi:10.1007/s11051-014-2572-2 
17. Derenskyi, V.; Gomulya, W.; Talsma, W.; Salazar-Rios, J. M.; Fritsch, M.; Nirmalraj, P.; Riel, H.; Allard, S.; Scherf, U.; Loi, M. A. Adv. Mater. (Weinheim, Ger.) 2017, 29, 1606757. doi:10.1002/adma.201606757

18. Bastings, M. M. C.; Koudstaal, S.; Kieltyka, R. E.; Nakano, Y.; Pape, A. C. H.; Feyen, D. A. M.; van Slochteren, F. J.; Doevendans, P. A.; Sluijter, J. P. G.; Meijer, E. W.; Chamuleau, S. A. J.; Dankers, P. Y. W. Adv. Healthcare Mater. 2014, 3, 70-78. doi:10.1002/adhm.201300076

19. Kakuta, T.; Takashima, Y.; Nakahata, M.; Otsubo, M.; Yamaguchi, H.; Harada, A. Adv. Mater. (Weinheim, Ger.) 2013, 25, 2849-2853. doi:10.1002/adma.201205321

20. Lu, H. D.; Charati, M. B.; Kim, I. L.; Burdick, J. A. Biomaterials 2012, 33, 2145-2153. doi:10.1016/j.biomaterials.2011.11.076

21. Bode, S.; Zedler, L.; Schacher, F. H.; Dietzek, B.; Schmitt, M.; Popp, J.; Hager, M. D.; Schubert, U. S. Adv. Mater. (Weinheim, Ger.) 2013, 25 1634-1638. doi:10.1002/adma.201203865

22. Chen, H.; Ma, X.; Wu, S.; Tian, H. Angew. Chem., Int. Ed. 2014, 53, 14149-14152. doi:10.1002/anie.201407402

23. Zhang, M.; Xu, D.; Yan, X.; Chen, J.; Dong, S.; Zheng, B.; Huang, F. Angew. Chem., Int. Ed. 2012, 51, 7011-7015. doi:10.1002/anie.201203063

24. Prathap, A.; Sureshan, K. M. Angew. Chem., Int. Ed. 2017, 56, 9405-9409. doi:10.1002/anie.201704699

25. Molji, C.; Aashish, A.; Neethu, K. S.; Devaki, S. J. J. Mater. Chem. A 2017, 5, 16636-16645. doi:10.1039/c7ta05215d

26. Dell'Elce, S.; Liscio, F.; Kovtun, A.; Allegri, S.; Roscioni, O. M.; Albonetti, C.; De Luca, G.; Amenitsch, H. W.; Demitri, N.; Giorgini, L.; Morandi, V.; Stellacci, F.; Liscio, A.; Palermo, V. Nanoscale 2018, 10 23018-23026. doi:10.1039/c8nr07109h

27. Bera, S.; Haldar, D. J. Mater. Chem. A 2016, 4, 6933-6939. doi:10.1039/c5ta08010j

28. Xie, S.; Wu, S.; Bao, S.; Wang, Y.; Zheng, Y.; Deng, D.; Huang, L.; Zhang, L.; Lee, M.; Huang, Z. Adv. Mater. (Weinheim, Ger.) 2018, 30, 1800683. doi:10.1002/adma.201800683

29. Cheng, H.-B.; Li, Z.; Huang, Y.-D.; Liu, L.; Wu, H.-C. ACS Appl. Mater. Interfaces 2017, 9, 11889-11894. doi:10.1021/acsami.7b00363

30. Zheng, J.; Zhu, G.; Li, Y.; Li, C.; You, M.; Chen, T.; Song, E.; Yang, R.; Tan, W. ACS Nano 2013, 7, 6545-6554. doi:10.1021/nn402344v

31. Molino, N. M.; Wang, S.-W. Curr. Opin. Biotechnol. 2014, 28, 75-82. doi:10.1016/j.copbio.2013.12.007

32. Liang, H.; Zhang, X.-B.; Lv, Y.; Gong, L.; Wang, R.; Zhu, X.; Yang, R.; Tan, W. Acc. Chem. Res. 2014, 47, 1891-1901. doi:10.1021/ar500078f

33. Albelda, M. T.; Frías, J. C.; García-España, E.; Schneider, H.-J. Chem. Soc. Rev. 2012, 41, 3859-3877. doi:10.1039/c2cs35008d

34. Biros, S. M.; Rebek, J., Jr.. Chem. Soc. Rev. 2007, 36, 93-104. doi:10.1039/b508530f

35. Kataev, E. A.; Müller, C. Tetrahedron 2014, 70, 137-167. doi:10.1016/j.tet.2013.11.010

36. Oshovsky, G. V.; Reinhoudt, D. N.; Verboom, W. Angew. Chem., Int. Ed. 2007, 46, 2366-2393. doi:10.1002/anie.200602815

37. Percec, V.; Johansson, G.; Ungar, G.; Zhou, J. J. Am. Chem. Soc. 1996, 118, 9855-9866. doi:10.1021/ja9615738

38. Engelkamp, H.; Middelbeek, S.; Nolte, R. J. M. Science 1999, 284, 785-788. doi:10.1126/science.284.5415.785

39. He, L.; Liu, X.; Liang, J.; Cong, Y.; Weng, Z.; Bu, W. Chem. Commun. 2015, 51, 7148-7151. doi:10.1039/c5cc00934k
40. Dong, S.; Zheng, B.; Xu, D.; Yan, X.; Zhang, M.; Huang, F. Adv. Mater. (Weinheim, Ger.) 2012, 24, 3191-3195. doi:10.1002/adma.201200837

41. Li, H.; Fan, X.; Qi, M.; Yang, Z.; Zhang, H.; Tian, W. Chem. - Eur. J. 2016, 22, 101-105. doi:10.1002/chem.201504012

42. Chen, D.; Zhan, J.; Zhang, M.; Zhang, J.; Tao, J.; Tang, D.; Shen, A.; Qiu, H.; Yin, S. Polym. Chem. 2015, 6, 25-29. doi:10.1039/c4py01206b

43. Hu, X.-Y.; Xiao, T.; Lin, C.; Huang, F.; Wang, L. Acc. Chem. Res. 2014, 47, 2041-2051. doi:10.1021/ar5000709

44. Ding, Y.; Wang, P.; Tian, Y.-K.; Tian, Y.-J.; Wang, F. Chem. Commun. 2013, 49, 5951-5953. doi:10.1039/c3cc42511h

45. Xiao, T.; Feng, X.; Wang, Q.; Lin, C.; Wang, L.; Pan, Y. Chem. Commun. 2013, 49, 8329-8331. doi:10.1039/c3cc44525a

46. Zhan, J.; Li, Q.; Hu, Q.; Wu, Q.; Li, C.; Qiu, H.; Zhang, M.; Yin, S. Chem. Commun. 2014, 50, 722-724. doi:10.1039/c3cc47468b

47. Wang, W.; Zhang, Y.; Sun, B.; Chen, L.-J.; Xu, X.-D.; Wang, M.; Li, X.; Yu, Y.; Jiang, W.; Yang, H.-B. Chem. Sci. 2014, 5, 4554-4560. doi:10.1039/c4sc01550a

48. Ji, X.; Chen, J.; Xue, M. Macromol. Chem. Phys. 2014, 215, 536-543. doi:10.1002/macp.201300691

49. Chen, L.; Tian, Y.-K.; Ding, Y.; Tian, Y.-J.; Wang, F. Macromolecules 2012, 45, 8412-8419. doi:10.1021/ma3016486

50. Li, S.; Weng, G.-H.; Lin, W.; Sun, Z.-B.; Zhou, M.; Zhu, B.; Ye, Y.; Wu, J. Polym. Chem. 2014, 5, 3994-4001. doi:10.1039/c4py00409d

51. Park, J.; Kim, K. Y.; Kim, C.; Lee, J. H.; Kim, J. H.; Lee, S. S.; Choi, Y.; Jung, J. H. Polym. Chem. 2018, 9, 3900-3907. doi:10.1039/c8py00644j

52. Xu, L.; Chen, D.; Zhang, Q.; He, T.; Lu, C.; Shen, X.; Tang, D.; Quu, H.; Zhang, M.; Yin, S. Polym. Chem. 2018, 9, 399-403. doi:10.1039/c7py01788j

53. Huang, G.; Jiang, W. Prog. Chem. 2015, 27, 744-754.

54. Zheng, B.; Wang, F.; Dong, S.; Huang, F. Chem. Soc. Rev. 2012, 41, 1621-1636. doi:10.1039/c1cs15220c

55. Dong, S.; Wang, L.; Wu, J.; Jin, L.; Ge, Y.; Qi, Z.; Wu, C. Langmuir 2017, 33, 13861-13866. doi:10.1021/acs.langmuir.7b03431

56. Qi, Z.; Chiappisi, L.; Gong, H.; Pan, R.; Cui, N.; Ge, Y.; Böttcher, C.; Dong, S. Chem. - Eur. J. 2018, 24, 3854-3861.

doi:10.1002/chem.201705838

57. Dong, S.; Leng, J.; Feng, Y.; Liu, M.; Stackhouse, C. J.; Schönhals, A.; Chiappisi, L.; Gao, L.; Chen, W.; Shang, J.; Jin, L.; Qi, Z.;

Schalley, C. A. Sci. Adv. 2017, 3, eaao0900. doi:10.1126/sciadv.aao0900

58. Singh, P.; Mittal, L. S.; Kaur, S.; Kaur, S.; Bhargava, G.; Kumar, S. Sens. Actuators, B 2018, 255, 478-489. doi:10.1016/j.snb.2017.08.072

59. Liu, K.; Xu, Z.; Yin, M. Prog. Polym. Sci. 2015, 46, 25-54. doi:10.1016/j.progpolymsci.2014.11.005

60. Dimitrakopoulos, C. D.; Malenfant, P. R. L. Adv. Mater. (Weinheim, Ger.) 2002, 14, 99-117. doi:10.1002/1521-4095(20020116)14:2<99::aid-adma99>3.0.co;2-9

61. Qu, J.; Mu, Z.; Lai, H.; Xie, M.; Liu, L.; Lu, W.; Chen, W.; He, F. ACS Appl. Energy Mater. 2018, 1, 833-840. doi:10.1021/acsaem.7b00277

62. Hadmojo, W. T.; Yim, D.; Aqoma, H.; Ryu, D. Y.; Shin, T. J.; Kim, H. W.; Hwang, E.; Jang, W.-D.; Jung, I. H.; Jang, S.-Y. Chem. Sci. 2017, 8, 5095-5100. doi:10.1039/c7sc01275f

63. Zhao, Y.; Wang, H.; Xia, S.; Zhou, F.; Luo, Z.; Luo, J.; He, F.; Yang, C. Chem. - Eur. J. 2018, 24, 4149-4156. doi:10.1002/chem.201705480

64. Sung, J.; Kim, P.; Fimmel, B.; Würthner, F.; Kim, D. Nat. Commun. 2015, 6, 8646. doi:10.1038/ncomms 9646 
65. Würthner, F. Chem. Commun. 2004, 1564-1579. doi:10.1039/b401630k

66. Li, X.-Q.; Zhang, X.; Ghosh, S.; Würthner, F. Chem. - Eur. J. 2008, 14, 8074-8078. doi:10.1002/chem.200800915

67. Gershberg, J.; Fennel, F.; Rehm, T. H.; Lochbrunner, S.; Würthner, F. Chem. Sci. 2016, 7, 1729-1737. doi:10.1039/c5sc03759j

68. Görl, D.; Zhang, X.; Stepanenko, V.; Würthner, F. Nat. Commun. 2015, 6, 7009. doi:10.1038/ncomms8009

69. Sung, J.; Nowak-Król, A.; Schlosser, F.; Fimmel, B.; Kim, W.; Kim, D.; Würthner, F. J. Am. Chem. Soc. 2016, 138, 9029-9032. doi:10.1021/jacs.6b04591

70. Wu, Y.; Young, R. M.; Frasconi, M.; Schneebeli, S. T.; Spenst, P.; Gardner, D. M.; Brown, K. E.; Würthner, F.; Stoddart, J. F.; Wasielewski, M. R. J. Am. Chem. Soc. 2015, 137, 13236-13239. doi:10.1021/jacs.5b08386

71. Chen, Z.; Lohr, A.; Saha-Möller, C. R.; Würthner, F. Chem. Soc. Rev. 2009, 38, 564-584. doi:10.1039/b809359h

72. Brixner, T.; Hildner, R.; Köhler, J.; Lambert, C.; Würthner, F. Adv. Energy Mater. 2017, 7, 1700236. doi:10.1002/aenm.201700236

73. Pochas, C. M.; Kistler, K. A.; Yamagata, H.; Matsika, S.; Spano, F. C. J. Am. Chem. Soc. 2013, 135, 3056-3066. doi:10.1021/ja3087449

74. Zhang, B.; Soleimaninejad, H.; Jones, D. J.; White, J. M.; Ghiggino, K. P.; Smith, T. A.; Wong, W. W. H. Chem. Mater. 2017, 29, 8395-8403. doi:10.1021/acs.chemmater.7b02968

75. Krieg, E.; Rybtchinski, B. Chem. - Eur. J. 2011, 17, 9016-9026. doi:10.1002/chem.201100809

76. Cohen, E.; Weissman, H.; Pinkas, I.; Shimoni, E.; Rehak, P.; Král, P.; Rybtchinski, B. ACS Nano 2018, 12, 317-326. doi:10.1021/acsnano.7b06376

77. Tidhar, Y.; Weissman, H.; Wolf, S. G.; Gulino, A.; Rybtchinski, B. Chem. - Eur. J. 2011, 17, 6068-6075. doi:10.1002/chem.201003419

78. Zhang, X.; Rehm, S.; Safont-Sempere, M. M.; Würthner, F. Nat. Chem. 2009, 1, 623-629. doi:10.1038/nchem.368

79. Zhang, X.; Chen, Z.; Würthner, F. J. Am. Chem. Soc. 2007, 129, 4886-4887. doi:10.1021/ja070994u

80. Ustinov, A.; Weissman, H.; Shirman, E.; Pinkas, I.; Zuo, X.; Rybtchinski, B. J. Am. Chem. Soc. 2011, 133, 16201-16211. doi:10.1021/ja2066225

81. Krieg, E.; Shirman, E.; Weissman, H.; Shimoni, E.; Wolf, S. G.; Pinkas, I.; Rybtchinski, B. J. Am. Chem. Soc. 2009, 131, 14365-14373. doi:10.1021/ja903938g

82. Langhals, H.; Jona, W.; Einsiedl, F.; Wohnlich, S. Adv. Mater. (Weinheim, Ger.) 1998, 10, 1022-1024. doi:10.1002/(sici)1521-4095(199809)10:13<1022::aid-adma1022>3.0.c o;2-0

83. Licchelli, M.; Orbelli Biroli, A.; Poggi, A. Org. Lett. 2006, 8, 915-918. doi:10.1021/ol053084v

84. Ma, Y.; Marszalek, T.; Yuan, Z.; Stangenberg, R.; Pisula, W.; Chen, L.; Müllen, K. Chem. - Asian J. 2015, 10, 139-143. doi:10.1002/asia.201403037

85. Weißenstein, A.; Würthner, F. Chem. Commun. 2015, 51, 3415-3418. doi:10.1039/c4cc09443c

86. Qi, Z.; Malo de Molina, P.; Jiang, W.; Wang, Q.; Nowosinski, K.; Schulz, A.; Gradzielski, M.; Schalley, C. A. Chem. Sci. 2012, 3, 2073-2082. doi:10.1039/c2sc01018f

87. Jiang, W.; Schalley, C. A. Beilstein J. Org. Chem. 2010, 6, No. 14. doi:10.3762/bjoc.6.14

88. Qi, Z.; Traulsen, N. L.; Malo de Molina, P.; Schlaich, C.; Gradzielski, M.; Schalley, C. A. Org. Biomol. Chem. 2014, 12, 503-510. doi:10.1039/c3ob41523f
89. Qi, Z.; Wu, C.; Malo de Molina, P.; Sun, H.; Schulz, A.; Griesinger, C.; Gradzielski, M.; Haag, R.; Ansorge-Schumacher, M. B.; Schalley, C. A. Chem. - Eur. J. 2013, 19, 10150-10159. doi:10.1002/chem.201300193

90. Huang, D.; Zhang, Q.; Deng, Y.; Luo, Z.; Li, B.; Shen, X.; Qi, Z.; Dong, S.; Ge, Y.; Chen, W. Polym. Chem. 2018, 9, 2574-2579. doi:10.1039/c8py00412a

91. Qi, Z.; Schlaich, C.; Schalley, C. A. Chem. - Eur. J. 2013, 19, 14867-14875. doi:10.1002/chem.201301951

92. Ge, Y.; Gong, H.; Shang, J.; Jin, L.; Pan, T.; Zhang, Q.; Dong, S.; Wang, Y.; Qi, Z. Macromol. Rapid Commun. 2019, 1800731. doi:10.1002/marc.201800731

93. Li, A. D. Q.; Wang, W.; Wang, L.-Q. Chem. - Eur. J. 2003, 9 , 4594-4601. doi:10.1002/chem.200305025

94. Dehm, V.; Büchner, M.; Seibt, J.; Engel, V.; Würthner, F. Chem. Sci. 2011, 2, 2094-2100. doi:10.1039/c1sc00435b

95. Fennel, F.; Gershberg, J.; Stolte, M.; Würthner, F. Phys. Chem. Chem. Phys. 2018, 20, 7612-7620. doi:10.1039/c7cp07778e

96. Beckers, E. H. A.; Meskers, S. C. J.; Schenning, A. P. H. J.; Chen, Z.; Würthner, F.; Janssen, R. A. J. J. Phys. Chem. A 2004, 108, 6933-6937. doi:10.1021/jp048980n

97. Würthner, F.; Thalacker, C.; Diele, S.; Tschierske, C. Chem. - Eur. J. 2001, 7, 2245-2253. doi:10.1002/1521-3765(20010518)7:10<2245::aid-chem2245>3.0.co;2w

98. Li, Z.-Y.; Zhang, Y.; Zhang, C.-W.; Chen, L.-J.; Wang, C.; Tan, H.; Yu, Y.; Li, X.; Yang, H.-B. J. Am. Chem. Soc. 2014, 136, 8577-8589. doi:10.1021/ja413047r

99. Chen, L.-J.; Zhao, G.-Z.; Jiang, B.; Sun, B.; Wang, M.; Xu, L.; He, J.; Abliz, Z.; Tan, H.; Li, X.; Yang, H.-B. J. Am. Chem. Soc. 2014, 136, 5993-6001. doi:10.1021/ja500152a

\section{License and Terms}

This is an Open Access article under the terms of the Creative Commons Attribution License (http://creativecommons.org/licenses/by/4.0). Please note that the reuse, redistribution and reproduction in particular requires that the authors and source are credited.

The license is subject to the Beilstein Journal of Organic Chemistry terms and conditions: (https://www.beilstein-journals.org/bjoc)

The definitive version of this article is the electronic one which can be found at: doi: $10.3762 /$ bjoc. 15.117 